\author{
А. В. Клименко \\ ORCID 0000-0002-8502-0769 \\ А. О. Стешенко \\ ORCID 0000-0002-0626-2533 \\ ResearcherID P-2988-2016 \\ ORCID 0000-0001-9891-2419 \\ ResearcherID P-8789-2016 \\ ORCID 0000-0002-5583-4921
}

O. В. Захарчук

В. С. Ткачов

Запорізький державний медичний університет

\title{
ДОСВІД ВИКОРИСТАННЯ ЛАПАРОСКОПІЧНОГО ТРЕНАЖЕРА 3 МЕТОЮ ПОКРАЩЕННЯ ПРАКТИЧНИХ НАВИЧОК СТУДЕНТІВ-МЕДИКІВ
}

\author{
A. V. Klymenko, A. O. Steshenko, O. V. Zakharchuk, V. S. Tkachov \\ Zaporizhzhia State Medical University \\ EXPERIENCE OF USING LAPAROSCOPIC TRAINER BOX \\ WITH THE AIM OF IMPROVING MEDICAL STUDENTS' PRACTICAL \\ SKILLS
}

\begin{abstract}
Анотація. В останні роки спостерігається експоненціальне збільшення ролі технічного оснащення в практиці лікаря хірургічного профілю. Міні-інвазивні хірургічні втручання зазнають широкої інтеграції та потребують від спеціаліста оволодіння певними специфічними навичками. Враховуючи наявність невідповідності навчальних програм сучасним тенденціям, виникає необхідність створення нових навчальних курсів. У статті показано досвід використання лапароскопічного тренажера для покращення практичних навичок студентів-медиків, які не мали попереднього досвіду лапароскопічної хірургії. На сконструйованому нами бокс-тренажері учасники пройшли навчальний курс, що складається з семи вправ. Оцінка покращення навичок була здійснена шляхом порівняння результатів учасників на початку і в кінці проходження курсу. Всі учасники змогли успішно виконати вправи, з досягненням поставленого цільового рівня. Всі студенти після проходження курсу покращили свої результати в середньому від 1,6 до 4,65 раза, залежно від вправи $(\mathrm{p}<0,05)$. Використання самостійно сконструйованих лапароскопічних бокс-тренажерів з розробленим у клініці комплексом вправ $є$ доцільним задля ефективного підвищення практичної підготовки і вмотивованості студентів-медиків. Раннє ознайомлення майбутніх спеціалістів із стандартами міні-інвазивної хірургії $\epsilon$ важливою складовою навчального процесу і допомагає створити інноваційно орієнтоване професійне мислення.
\end{abstract}

Ключові слова: лапароскопія; міні-інвазивна хірургія; навчальна модель; симуляція; студенти-медики; освіта.

Abstract. During the last years an exponential increase of technical equipment role is being observed in surgical practice. Minimally invasive surgical interventions are widely integrated and require specialists to acquire specific skills. Considering inconsistency between educational programs and modern tendencies, there is a need to create new training courses. The article describes experience of laparoscopic trainer box application for improving medical students' practical skills, who had no laparoscopic experience in the past. Participants completed training course, consisting of seven exercises, on constructed by us laparoscopic box trainer. Assessment of skill improvement was performed, comparing participants' results at the beginning and end of the course. All participants were able to successfully complete each of the seven laparoscopic exercises, with accomplishment of target level up to the last set. All students refined upon their results in the average from 1.6 to 4.65 times, depending on the exercise. Constructed in the clinic laparoscopic box trainer with the suite of exercises is useful and reasonable for effective increase of practical skills level and motivation of medical students. Early introducing future specialists with standards of mini-invasive surgery is an important part of their educational process and helps to create innovation oriented professional thinking.

Key words: laparoscopy; minimally invasive surgery; educational model; simulation; medical students; education.

(c) А. В. Клименко, А. О. Стешенко, О. В. Захарчук, В. С. Ткачов 
Вступ. У сучасній хірургічній практиці спостерігається стрімкий ріст частки оперативних втручань, виконаних із застосуванням міні-інвазивних технологій, численні переваги яких вже є безсумнівними. В умовах різностороннього освітлення цієї теми з наукового боку, та розповсюдження малоінвазивних методів у практиці ургентної та планової хірургії, у спеціалістів хірургічного профілю виникає необхідність оволодіння певними унікальними навичками, специфіка яких суттєво відрізняється від тих, які вимагаються традиційними техніками операцій. До них відносяться адаптація до тривимірного візуального просторового сприйняття, керуючись двовимірним зображенням на екрані; використання інструментів великої довжини з посиленим тремором; пристосування до fulcrum-ефекту (ефекту скованості) та до зниження зворотного тактильного зв'язку.

Традиційно опанування практичних навичок та підвищення технічних вмінь молодого спеціаліста відбувається практично виключно в операційній, шляхом асистування більш досвідченому хірургу, який суб'єктивно відстежує прогрес. Водночас, по-перше, було визнано, що сучасна операційна через підвищення вартості, стресу, обмеженості часу й етичних зауважень не $є$ ідеальним навчальним середовищем [8]. По-друге, лапароскопічна хірургія погано адаптується до поширених моделей навчання загальної хірургічної практики, що вимагає використання навчальних програм, які включають інструменти оцінки набуття і підтвердження оволодіння навичками; цільові показники ефективності й чітко сформульований навчальний план, що можуть бути легко пояснені практикантам інструктором [15].

Доведено високу ефективність лапароскопічних бокс-тренажерів у формуванні лапароскопічних навичок [6]. Тренування на симуляційних моделях веде до швидшого темпу навчання окремого хірурга в безпечних і керованих умовах, таким чином зменшуючи час і витрати реальних міні-інвазивних втручань, при цьому підвищуючи їх безпечність для пацієнта $[10,11,13,16]$. В той же час, хоча існує багато комерційних курсів симуляційного навчання, а в деяких закладах воно проводиться для спеціалістів і резидентів хірургічного профілю безоплатно, студенти-медики здебільшого не отримують жодного тренування лапароскопічних навичок протягом їх навчання у вищих медичних закладах $[4,7,9,12,14]$. Це створює різкий дисонанс з сучасною хірургічною практикою, яка все більше по- кладається на арсенал міні-інвазивних технологій. Хоча питання лапароскопічної підготовки студентів продовжує вивчатися, кількість досліджень залишається невеликою $[5,12]$. Це вказує на доцільність підвищення доступності опанування навичок міні-інвазивної хірургії шляхом створення нових можливостей для лапароскопічного тренування.

Мета дослідження - оцінити результати тренування студентів на лапароскопічному бокстренажері з розробленим у клініці комплексом вправ, використовуючи стандарти навчання практичних навичок міні-інвазивної хірургії.

Методи дослідження. У дослідженні взяли участь 10 студентів 4 курсу медичного факультету, яким за рандомним принципом було запропоновано взяти участь у дослідженні. Учасники раніше особисто не виконували лапароскопічні втручання, не асистували при них і не використовували подібне обладнання чи інструменти до початку цього курсу. Тривалість курсу була 5 місяців.

Симуляційний бокс-тренажер був розроблений і виготовлений на кафедрі факультетської хірургії ЗДМУ та складався з прозорого пластикового контейнера, розмірами 45×37x24,5 см, передню черевну стінку якого імітує кришка контейнера, обклеєна синьою непрозорою тканиною, яка має 4 отвори для інструментів. Бокс оснащений системою освітлення, що включає в себе розміщену по периметру світлодіодну стрічку і ліхтар у центрі зворотної частини кришки, а також фіксованою камерою, зображення з якої проектується на екран ноутбука, який встановлюється зверху контейнера. Для виконання вправ використовувалися дисектор 3 вигнутими браншами типу Меріленд й атравматичний затискач з кремальєрою. Для вимірювання часу використовувався електронний секундомір. Статистична обробка проводилася за допомогою програми SPSS Statistics v.23. Для кожного завдання, виконуваного учасниками, для знаходження значущих статистичних відмінностей між результатами до та після проходження курсу, використовувався непараметричний критерій Вілкоксона із знаковими парними рангами, а значення $\mathrm{p}<0,05$ вважалося статистично значущим. Стан нормальності змінних величин був проаналізований тестом Колмогорова - Смирнова.

Результати дослідження. Було розроблено 7 вправ: «Переміщення горошин», «Оберт паличок», «Нанизування намистин», «Проста петля», «Подвійна петля», «Хірургічний вузол», «Змійка». Послідовність завдань була направлена на поступове 
набуття і покращення навичок протягом курсу. Для кожної вправи було написано детальну інструкцію, визначений цільовий рівень і кількість підходів, необхідних для його досягнення. Цільовий рівень був встановлений до початку курсу, виходячи з власно- го досвіду авторів при виконанні вправ. У центрі боксу була розташована фіксована платформа, обладнана всім необхідним для виконання 1, 2, 4, 5 і 6 вправ (рис. 1). Перед нею встановлювалися зйомні модулі, які потрібні для здійснення вправ 3 і 7.
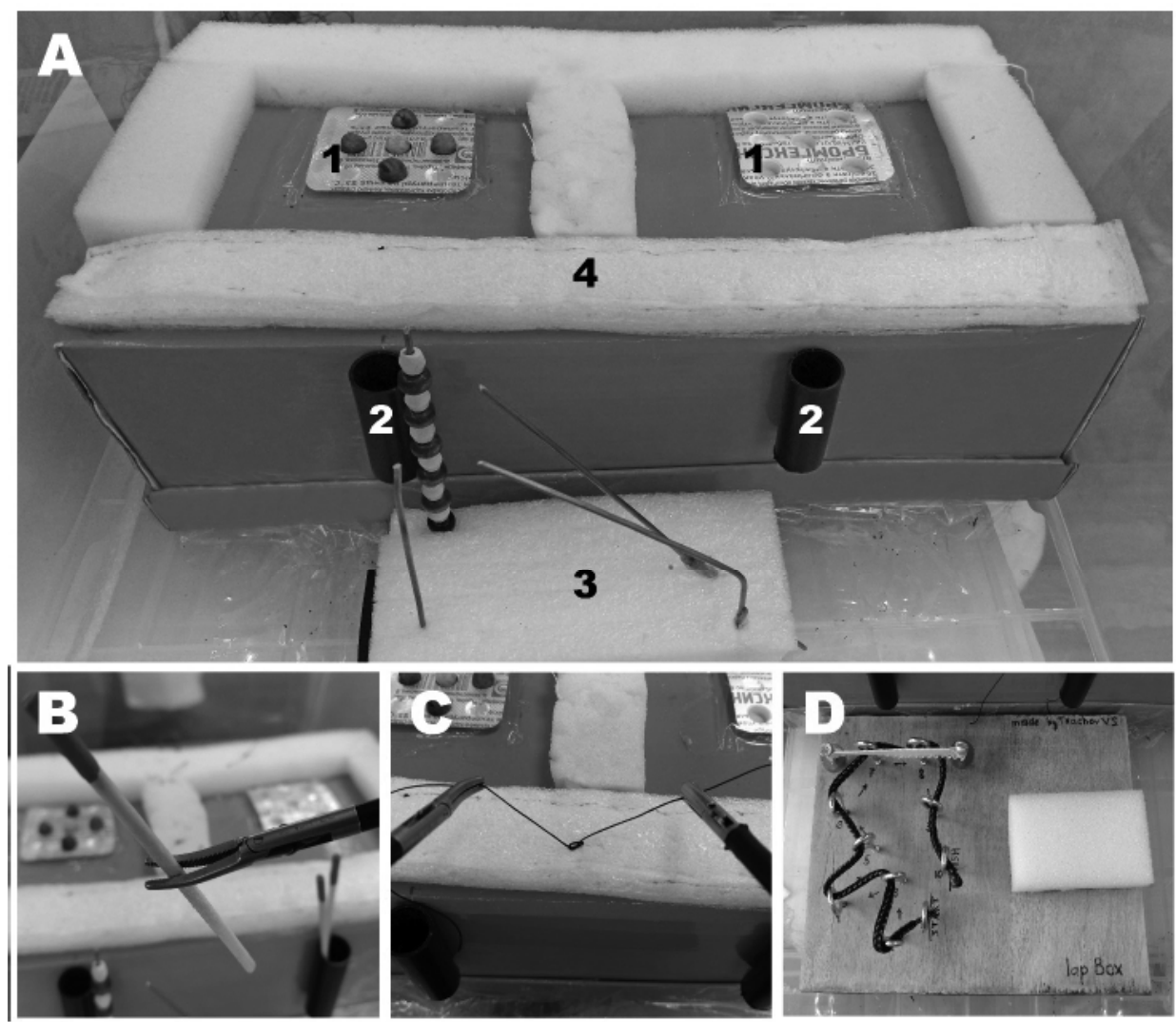

Рис. 1. А - внутрішній вигляд боксу: 1 - планшетки з комірками для вправи 1 ;

2 - циліндри для вправи 2; 3 - зйомний модуль для вправи 3; 4 - блок пенополістеролу для вправ 4-6;

В - палички для вправи 2; C - приклад закріплення нитки для вправ 4-6; D - зйомний модуль для вправи 7.

\section{Вирава 1}

«Переміщення горошин». П’ять горошин розташовані в лівій частині платформи. Горошини треба підняти лівою рукою і розташувати у рівновіддалену комірку з протилежного боку. Після успішного переміщення всіх п’яти горошин на інший бік вправу слід повторити у протилежному напрямку, починаючи з правої руки.

\section{Вправа 2}

«Оберт паличок». Три, марковані з одного боку, палички розміщені в циліндрі з правого боку. Палички необхідно взяти правою рукою, повернути на $180^{\circ}$ і вставити в циліндр з іншого боку. Після того як усі палички будуть успішно переміщені, вправу повторюють лівою рукою у протилежному напрямку.

\section{Вправа 3}

«Нанизування намистин». Різнокольорові дерев’яні намистини розташовані на вертикально розміщеному відрізку дроту. Намистини захоплюють лівою рукою і нанизують по одній на відрізки дроту в такій послідовності: першу - на вертикальний стрижень, другу - на стрижень під кутом $60^{\circ}$, третю - на стрижень під кутом 45․ Дії повторюють правою рукою.

\section{Вирава 4}

«Проста петля». Закріплений відрізок білого пенополістеролу прошитий чорною шовковою 2.0 ниткою. Один кінець захоплюють однією рукою, іншою рукою формують і затягують одинарну просту петлю. Необхідно сформувати по 5 петель кожною рукою. 


\section{Вирава 5}

«Подвійна петля». Аналогічно вправі 4, утворюють і затягують подвійну петлю. Потрібно сформувати по 3 петлі кожною рукою.

Вирава 6

«Хірургічний вузол». Використовуючи праву руку як домінантну, послідовно формують і затягують подвійну петлю і дві простих одинарних петлі. Лівою рукою повторити.

\section{Вирава 7}

«Змійка». Модуль з кільцями встановлюється так, щоб перше кільце було ближче, а десяте далі від учасника. Шнурок лежить паралельно лінії старту. Шнурок повинен бути послідовно проведений через усі десять кілець у порядку зростання їх нумерації. При проведенні шнурка через сьоме і восьме кільця необхідно однією рукою відтягнути резинку догори, іншою просуваючи шнурок. При виконанні завдання використовують обидві руки.

Перед кожною вправою учасникам були дані вичерпні інструкції. Далі кожна вправа була усно коротко пояснена і продемонстрована інструктором. В подальшому для підвищення ефективності навчання за рахунок тактильного зворотного зв'язку всім учасникам був по черзі наданий доступ до складових елементів вправ з метою їх візуального і тактильного обстеження. Задля досягнення конструктної валідності всі учасники мали до 5 хв на адаптацію і просторову орієнтацію, після цього вони виконували ознайомлювальний підхід перед виконанням кожної вправи.

Результати дослідження представлені як середні, медіани, мінімальні й максимальні значення і стандартні відхилення (табл. 1).

Таблиця 1. Середнє відносне покращення результатів виконання вправ

\begin{tabular}{|l|c|c|c|}
\hline & $\begin{array}{c}\text { Перший підхід, середній } \\
\text { результат (с) }\end{array}$ & $\begin{array}{c}\text { Останній підхід, серед- } \\
\text { ній результат (с) }\end{array}$ & Покращення \\
\hline Впр. 1 & $326,6 \pm 37,9$ & $106,4 \pm 9,3$ & $3,09 \pm 0,45$ \\
\hline Впр. 2 & $354,5 \pm 106,1$ & $81,7 \pm 14,8$ & $4,49 \pm 1,65$ \\
\hline Впр. 3 & $705,2 \pm 146,9$ & $155,2 \pm 22,6$ & $4,65 \pm 1,3$ \\
\hline Впр. 4 & $838,6 \pm 105,5$ & $233,5 \pm 12$ & $3,76 \pm 0,51$ \\
\hline Впр. 5 & $255,6 \pm 26$ & $159,6 \pm 9,6$ & $1,6 \pm 0,18$ \\
\hline Впр. 6 & $180,3 \pm 22,8$ & $100,2 \pm 11,5$ & $1,8 \pm 0,12$ \\
\hline Впр. 7 & $368,2 \pm 54,6$ & $200,8 \pm 8,9$ & $1,83 \pm 0,24$ \\
\hline
\end{tabular}

Примітка. (Середнє \pm стандартне квадратичне відхилення).

14 студентів було запрошено для участі в дослідженні. 4 з них було виключено у зв'язку з їх неможливістю регулярного відвідування курсу, 10 учасників успішно завершили курс. Протягом усієї тренувальної програми кожен учасник успішно виконав кожну з семи вправ. Успішне виконання завдання було визначено як спроможність виконати кожну вправу від початку до кінця самостійно, без допомоги інструктора, з досягненням на останньому підході поставленого цільового рівня.

За допомогою критерію знакових рангів Вілкоксона доведено $(\mathrm{P}<0,05)$ достовірність статистичних відмінностей між початковим і кінцевим результатом.

На рисунках 2 і 3 представлений час у секундах для виконання кожного завдання, який був потрібен учасникам для завершення першого і останнього підходів відповідно, у формі box-plot діаграми.

Графічне зображення результатів 2, 3 і 4 вправ на початку їх виконання показують досить широкий діапазон значень, що вказує на різний рівень підготовки учасників до навчальних цілей, які були поставлені перед ними вправою. Перша вправа $€$ найпростішою з усього курсу; не ставлячи складних завдань і вимагаючи насамперед покращення просторової орієнтації, вона була виконана студентами з відносно невеликим розбігом значень. 5 і 6 вправи вимагають використання вже набутих навичок у вправі 4, лише зменшуючи ліміт часу, що відображається на діаграмі звуженням амплітуди. Вправа 7, хоча і пропонує інтегроване використання навичок, опанованих учасником протягом курсу, потребує здійснення точно вивірених рухів, одночасно виконуваних обома руками, що вплинуло на розподіл результатів між 1 і 3 квартилями діаграми. Розташування медіани у результатах вправ $1 \mathrm{i}$ 5 вказує на асиметрію розподілу даних, яка, тим не менш, вкладається у межі статистичної достовірності.

Зображення результатів вправ 4, 5, 6 та 7 відображають помірний розподіл між 1 та 3 квартилями діаграми, з тенденцією до збільшення амплітуди у бік мінімальних значень, що свідчить про вирівнювання суб’єктивної складності цих завдань 


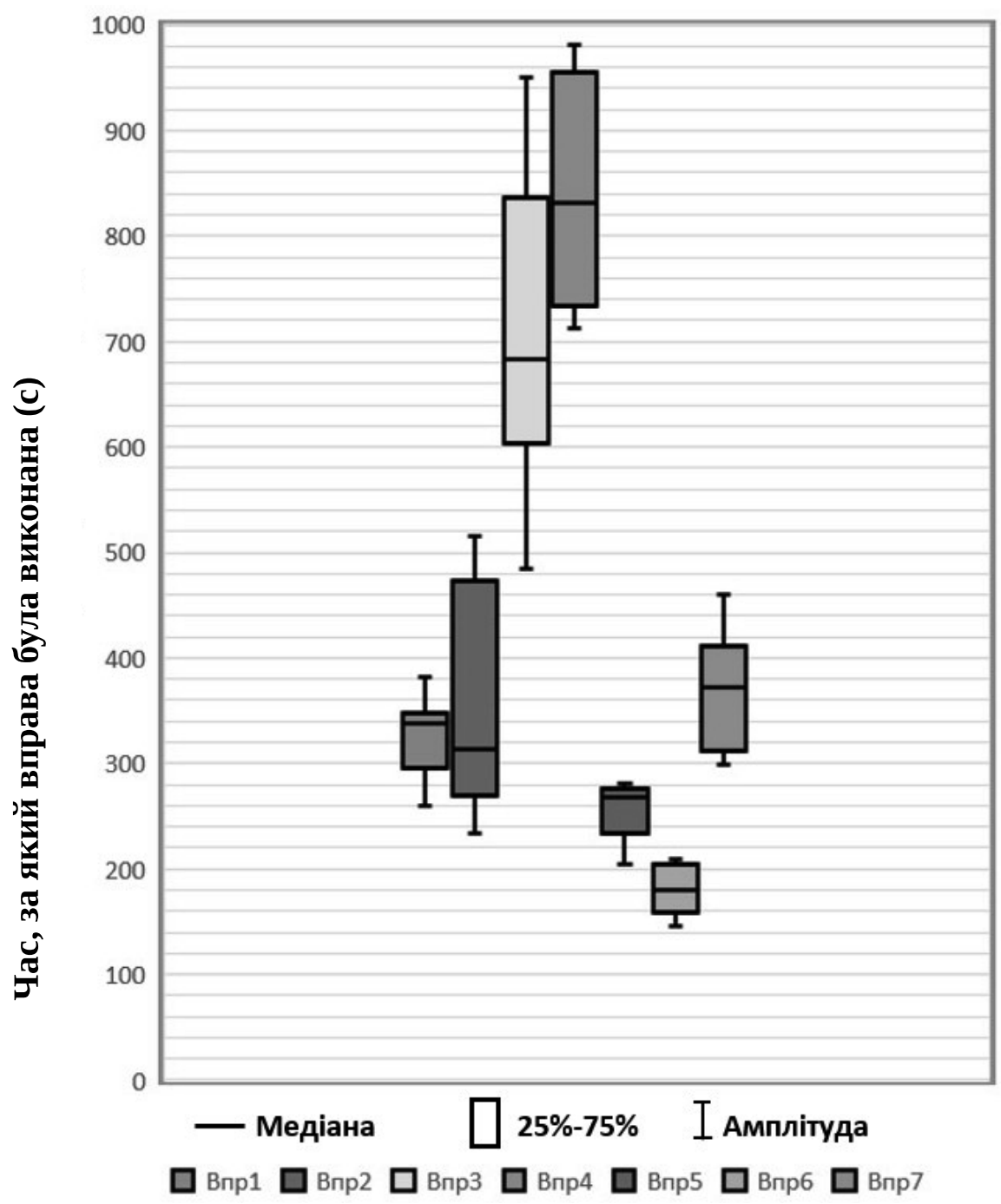

Рис. 2. Час, необхідний для завершення вправи на першому підході.

поміж учасниками курсу. На діаграмі видно викид - результат виміру, що виділяється з загальної вибірки результатів вправи 1; це зумовлено високою концентрацією навколо цільового рівня й високою робастністю використовуваного методу, і відмінності, виражені у вигляді абсолютних значень, нівелюють виникнення даного ефекту. У вправах 2 і 3 помітна широка дисперсність результатів, що, при симетричному розподілі між квантилями, свідчить про різний ступінь покращення вихідних навичок учасників.

На рис. 4 відображено порівняння початкових і підсумкових результатів з досягненням цільового рівня. 3 рис. 4 видно, що найбільш суттєвого покращення було досягнуто при виконанні 2, 3 і 4 вправ; зменшення амплітуди стандартних квадратичних відхилень на останньому підході дає змогу говорити про стабільність виконання студентами поставлених цілей. Рисунок показує: довше за все, з найбільшою дисперсією початкових результатів, виконані вправи 3 і 4, що корелює із значним підвищенням їх складності. Відносно невисокий прогрес 5 і 6 вправ, проілюстрований на рисунку, може бути зумовлений схожістю їх навчальних елементів із попереднім завданням. Знаходження середнього значення всіх вправ нижче лінії, що визначає цільовий рівень, свідчить про його досягнення всіма учасниками курсу.

Набуття специфічних навичок міні-інвазивної хірургії потребує своєрідного тренування з використанням методів, що суттєво відрізняються від технік традиційної хірургії. Протягом трьох останніх десятиріч прогресивно накопичувалися дані на користь доцільності застосування симуляційних тренажерів як інструмента навчання і засобу оцінки в галузі лапароскопії. В той час як варіабельність 


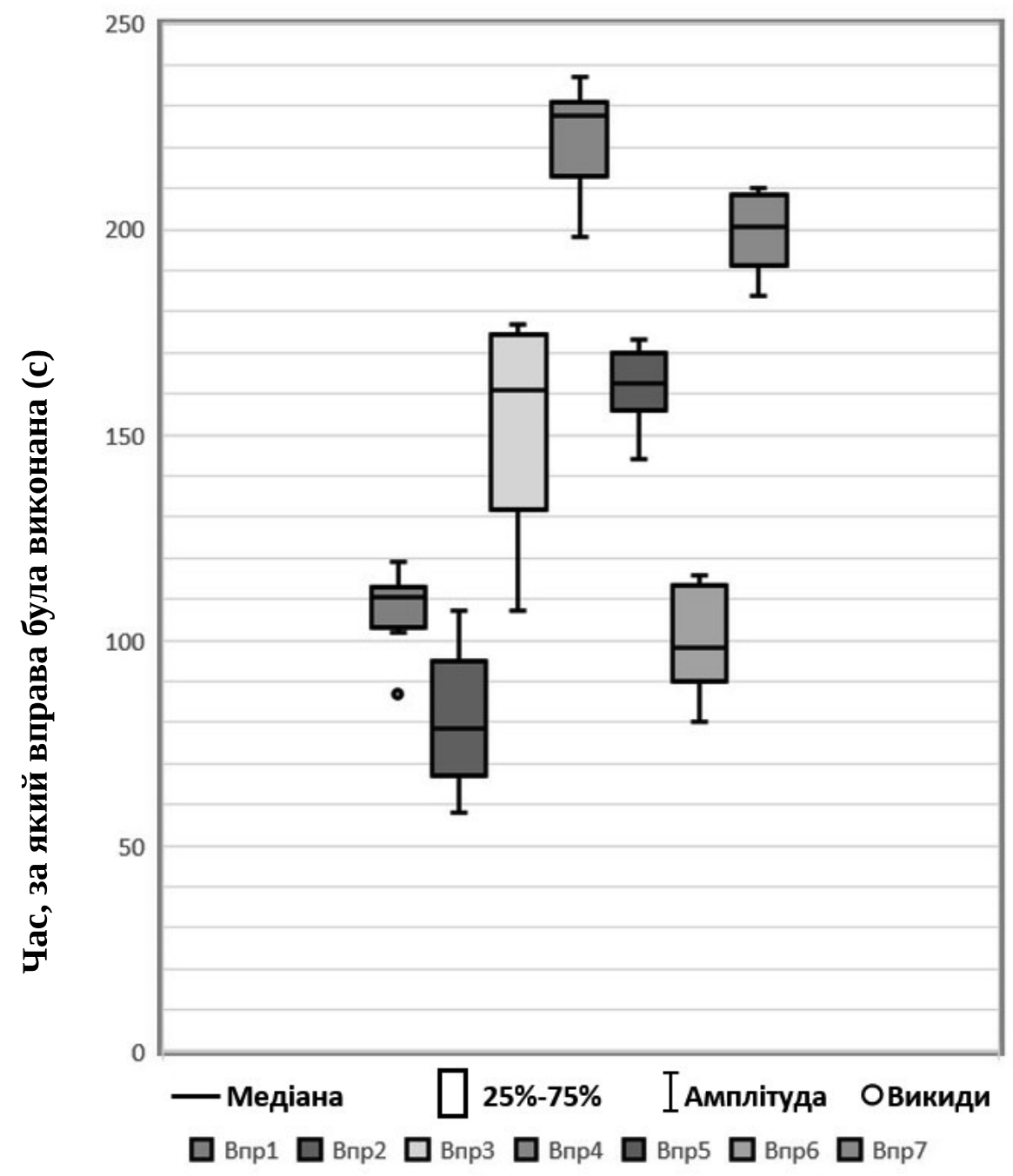

Рис. 3. Час, необхідний для завершення вправи на останньому підході.

симуляторів і різноманітність їх конструкцій постійно збільшується, все ще існує плутанина в тому, яким чином можна досягти їх найефективнішого застосування для набуття хірургічних навичок. Покращення ефективності навчання можна досягти, керуючись програмою, що дозволяє послідовно оволодіти базовими елементами міні-інвазивної хірургії, забезпечуючи поступове підвищення складності, та яка надає можливість оцінювати прогрес, забезпечуючи швидкий зворотний зв'язок. Хоча на даний момент існують офіційно затверджені програми, що включають всі необхідні елементи, вони пристосовані для вживання лише 3 тренажерами певної конструкції і потребують адаптації при використанні інших моделей [14, 17].

Численні дослідження довели переваги використання самостійно сконструйованих тренажерів невисокої вартості задля хірургічної підготовки та їх надійність в оцінці набутих навичок [3, 7, 12]. Chandrasekera et al. використали сліпе рандомізоване дослідження при порівнянні ефективності дешевої моделі, створеної з картонної коробки i традиційного відеолапароскопічного тренажера, дані якого свідчать про відсутність статистично значущих відмінностей між результатами студентів двох груп [2]. Очевидно, що найбільшою перешкодою до регулярного тренування є висока вартість моделей, представлених на ринку, і найбільш значущою перевагою самостійно зроблених боксів стає їх низька вартість. Найдорожчими складовими таких боксів $є$ лапароскопічні інструменти й камера, яким на даний момент не існує дешевших альтернатив. Враховуючи основне припущення, що рівень практичних навичок пропорційно залежить від часу, витраченого спеціалістом на його вдосконалення, тренування необхідно починати 


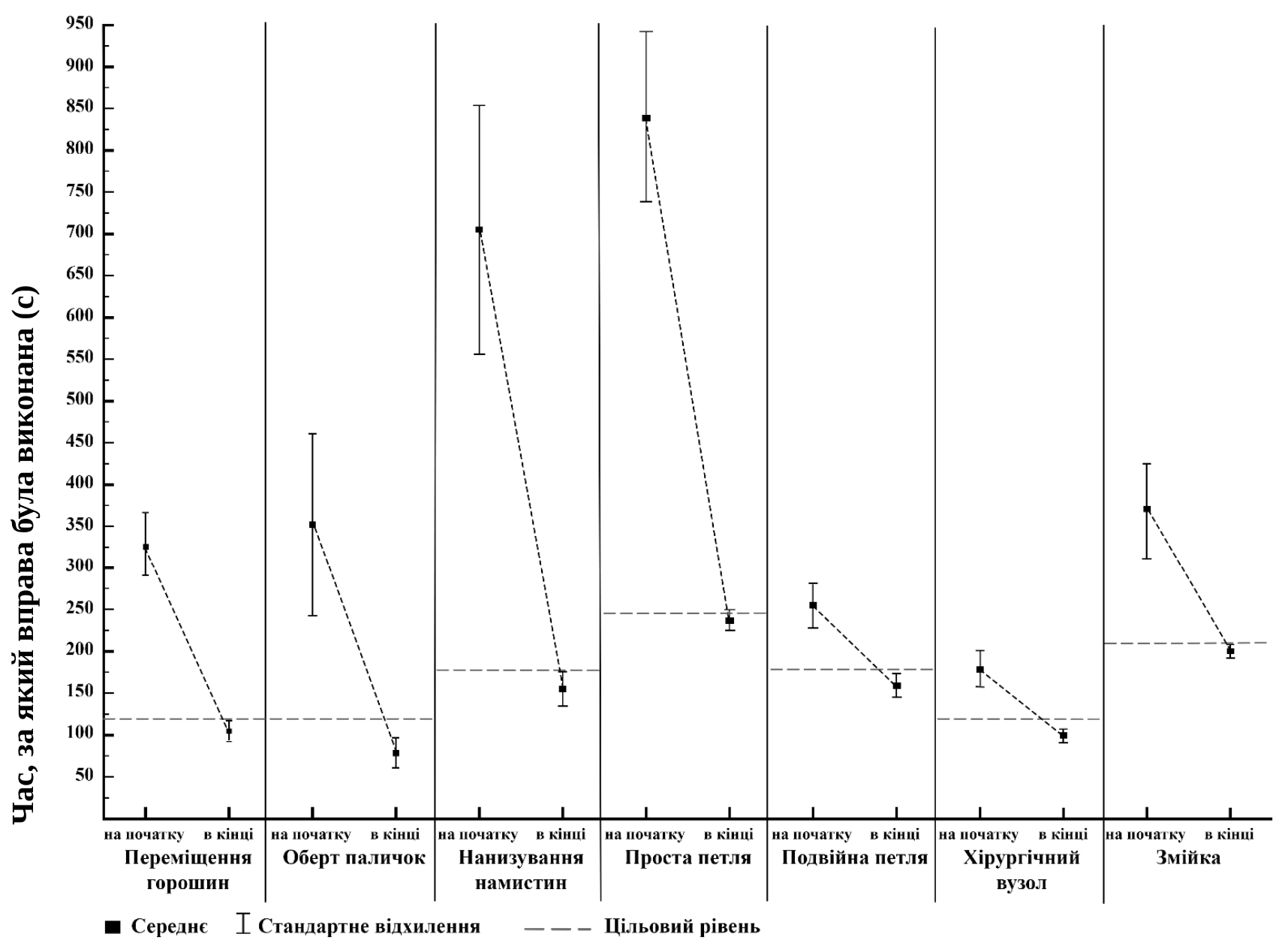

Рис. 4. Результати на початку і в кінці виконання кожної вправи.

якомога раніше, тобто ще під час навчання у вищих медичних закладах. При відсутності затверджених програм у навчальному плані симуляційне навчання доцільно проводити в якості гурткових і факультативних занять.

Однією з найбільших проблем для студентів, при проведені занять у формі факультативу, залишається неможливість їх регулярного відвідування. Зокрема, нам довелося виключити чотирьох учасників з чотирнадцяти, що складає 28,6 \%, 3 вищевказаної причини. На нашу думку, це можна виправити, наприклад, шляхом створення відповідного профільного курсу за вибором. Це надасть можливості до самовдосконалення професійно орієнтованим студентам з високим рівнем самосвідомості [1].

Найдоцільнішим форматом проведення занять курсу ми вважаємо заняття в групах по 3-4 студенти $з$ одним інструктором на один лапароскопічний бокс. Тривалість одного заняття 1,5-3 год. Це до- зволяє раціонально використовувати час, присвячуючи його інтенсивній практиці, при цьому даючи можливість відпочинку для незайнятих учасників.

Висновки та перспективи подальших досліджень. 1. Студенти-медики без попереднього лапароскопічного досвіду суттєво покращили свої показники у виконанні базових навчальних завдань міні-інвазивної хірургії протягом проходження розробленого курсу.

2. Використання самостійно сконструйованих лапароскопічних бокс-тренажерів 3 комплексом вправ $є$ доцільним задля підвищення практичної підготовки і вмотивованості студентів-медиків.

3. Потребуються подальші рандомізовані контрольовані дослідження за участі великої кількості студентів та можливості перевірки отриманих знань на сучасних анімалістичних моделях.

Конфлікт інтересів: відсутній. 


\section{Список літератури}

1. Лятуринська О. В. Роль самостійної роботи студентів на кафедрі дитячої хірургії / О. В. Лятуринська, М. О. Макарова // Запорожский медицинский журнал. - 2014. - № 1 (82). - C. 116-119.

2. Basic laparoscopic surgical training: examination of a low-cost alternative / S. K. Chandrasekera, J. F. Donohue, D. Orley [et al.] // European Urology. - 2006. - Vol. 50. P. 1285-1291.

3. Comparison of 2 training programs for basic laparoscopic skills and simulated surgery performance in veterinary students / C. Chen, C. Ragle, R. Lencioni [et al.] // Veterinary Surgery. - 2017. - Vol. 46. - P. 1187-1197.

4. Derossis A. M. Evaluation of laparoscopic skills: a 2-year follow-up during residency training / A. M. Derossis, M. Antoniuk, G. M. Fried // Canadian Journal of Surgery. 1999. - Vol. 42. - P. 293-296.

5. Development of laparoscopic skills in medical students naive to surgical training / W. L. Cavalini, C. M. Claus, D. Dimbarre [et al.] // Einstein (São Paulo). - 2014. - Vol. 12, Issue 4. - P. 467-472.

6. Effectiveness of box trainers in laparoscopic training / A. K. Dhariwal, R. Y. Prabhu, A. N. Dalvi, A. N. Supe // Journal of Minimal Access Surgery. - 2007. - Vol. 3, Issue 2. - P. 57-63.

7. Evaluating minimally invasive surgery training using low-cost mechanical simulations / G. L. Adrales, U. B. Chu, D. B. Witzke [et al.] // Surgical Endoscopy. - 2003. - Vol. 17, Issue 4. - P. 580-585.

8. Feldman L. S. Using simulators to assess laparoscopic competence: ready for widespread use? / L. S. Feldman, V. Sherman, G. M. Fried // Surgery. - 2004. - Vol. 135. P. 28.

9. Introduction of a comprehensive training curriculum in laparoscopic surgery for medical students: a randomized

\section{References}

1. Liaturinska, O.V., \& Makarova, M.O. (2014). Rol samostiinoi roboty studentiv na kafedri dytiachoi khirurhii [Students individual work on pediatric surgery chair as one of credit-transfer education system factors]. Zaporozhskyi medytsynskiy zhurnal - Zaporozhye Medical Journal, 1 (82), 116-119 [in Ukrainian].

2. Chandrasekera, S.K., Donohue, J.F., \& Orley, D. (2006). Basic laparoscopic surgical training: examination of a lowcost alternative. European Urology, 50, 1285-1291. DOI: 10.1016/j.eururo.2006.05.052.

3. Chen, C., Ragle, C., Lencioni, R., \& Fransson, B.A. (2017). Comparison of 2 training programs for basic laparoscopic skills and simulated surgery performance in veterinary students. Veterinary Surgery, 46, 1187-1197. DOI: 10.1111/vsu.12729.

4. Derossis, A.M., Antoniuk, M., \& Fried, G.M. (1999). Evaluation of laparoscopic skills: a 2-year follow-up during trial / N. Gawad, B. Zevin, E. M. Bonrath [et al.] // Surgery. - 2014. - Vol. 156, Issue 3. - P. 698-706.

10. Laparoscopic skills training using inexpensive box trainers: which exercises to choose when constructing a validated training course / H. Schreuder, C. van den Berg, E. Hazebroek [et al.] // BJOG - An International Journal of Obstetrics and Gynaecology. - 2011. - Vol. 118. P. 1576-1584.

11. Laparoscopic suturing skills acquisition: a comparison between laparoscopy-exposed and laparoscopy-naive surgeons / V. K. Bansal, T. Tamang, M. C. Misra [et al.] // Journal of the Society of Laparoendscopic Surgeons. - 2012. - Vol. 16. - P. 623-631.

12. Low-cost laparoscopic skill training for medical students using homemade equipment / T. Sellers, M. Ghannam, K. Asantey [et al.] // MedEdPORTAL. - 2019. - Vol. 15. - P. 10810

13. Proving the value of simulation in laparoscopic surgery / G. M. Fried, L. S. Feldman, M. C. Vassiliou [et al.] // Annals of Surgery. - 2004. - Vol. 240. - P. 518-525.

14. Reliability testing of a modified MISTELS score using a low-cost trainer box / A. Hasnaoui, H. Zaafouri, D. Haddad [et al.] // BMC Medical Education. - 2019. Vol. 19, Issue 1. - P. 132.

15. Rosser J. C. Objective evaluation of a laparoscopic surgical skill program for residents and senior surgeons / J. C. Rosser, L. E. Rosser, R. S. Savalgi // Archives of Surgery. - 1998. - Vol. 133. - P. 657-661.

16. Should medical students be given laparoscopic training? / T. Shakir, T. Lee, J. Lim [et al.] // Gynecological Surgery. - 2014. - Vol. 11. - P. 241.

17. The MISTELS program to measure technical skill in laparoscopic surgery / M. Vassiliou, G. Ghitulescu, L. Feldman [et al.] // Surgical Endoscopy. - 2006. - Vol. 20, Issue 5. - P. 744-747.

residency training. Canadian Journal of Surgery, 42, 293296.

5. Cavalini, W.L.P., Claus, C.M.P., \& Dimbarre, D. (2014). Development of laparoscopic skills in medical students naive to surgical training. Einstein (Sao Paulo), 12 (4), 467-472. DOI: $10.1590 /$ s1679-45082014ao3237.

6. Dhariwal, A.K., Prabhu, R.Y., Dalvi, A.N., \& Supe, A.N. (2007). Effectiveness of box trainers in laparoscopic training. Journal of Minimal Access Surgery, 3 (2), 57-63. DOI: 10.4103/0972-9941.33274.

7. Adrales, G.L., Chu, U.B., \& Witzke, D.B. (2003). Evaluating minimally invasive surgery training using lowcost mechanical simulations. Surgical Endoscopy, 17 (4), 580-585. DOI: 10.1007/s00464-002-8841-7.

8. Feldman, L.S., Sherman, V., \& Fried, G.M. (2004). Using simulators to assess laparoscopic competence: ready for widespread use? Surgery, 135, 28. DOI: 10.1016/s00396060(03)00155-7. 
9. Gawad, N., Zevin, B., Bonrath, E.M., Dedy, N.J., Louridas, M., \& Grantcharov, T.P. (2014). Introduction of a comprehensive training curriculum in laparoscopic surgery for medical students: a randomized trial. Surgery, 156 (3), 698-706. DOI: 10.1016/j.surg.2014.04.046.

10. Schreuder, H., van den Berg, C., Hazebroek, E., Verheijen, R., Schijven, M. (2011). Laparoscopic skills training using inexpensive box trainers: which exercises to choose when constructing a validated training course. BJOG, 118, 1576-1584. DOI: 10.1111/j.1471-0528.2011.03146.x.

11. Bansal, V.K., Tamang, T., \& Misra, M.C. (2012). Laparoscopic suturing skills acquisition: a comparison between laparoscopy-exposed and laparoscopy-naive surgeons. JSLS, 16, 623- 631. DOI: 10.4293/108680812x 13462882737375.

12. Sellers, T., Ghannam, M., Asantey, K., Klei, J., Olive, E., \& Roach, V. (2019). Low-cost laparoscopic skill training for medical students using homemade equipment. MedEdPORTAL, 15, 10810. DOI: 10.15766/mep_23748265.10810.
13. Fried, G.M., Feldman, L.S., Vassiliou, M.C., Fraser, S.A., Stanbridge, D., \& Ghitulescu, G. (2004). Proving the value of simulation in laparoscopic surgery. Annals of Surgery, 240, 518-525. DOI: 10.1097/01. sla.0000136941.46529.56.

14. Hasnaoui, A., Zaafouri, H., Haddad, D., Bouhafa, A., \& Ben Maamer, A. (2019). Reliability testing of a modified MISTELS score using a low-cost trainer box. BMC Medical Education., 19 (1), 132. DOI: 10.1186/s12909-019-1572-4.

15. Rosser, J.C., Rosser, L.E., \& Savalgi, R.S. (1998). Objective evaluation of a laparoscopic surgical skill program for residents and senior surgeons. Archives of Surgery, 133, 657-661. DOI: 10.1001/archsurg.133.6.657.

16. Shakir, T., Lee, T., \& Lim, J. (2014). Should medical students be given laparoscopic training? Gynecological Surgery, 11, 241. DOI:10.1007/s10397-014-0870-4.

17. Vassiliou, M., Ghitulescu, G., \& Feldman, L. (2006). The MISTELS program to measure technical skill in laparoscopic surgery. Surgical Endoscopy, 20 (5), 744-747. DOI: 10.1007/s00464-005-3008-y. 